\title{
Sources of Variability of Evapotranspiration in California
}

\author{
Hugo G. HidAlgo \\ Climate Research Division, Scripps Institution of Oceanography, University of California, San Diego, La Jolla, California \\ DANIEL R. CAYAN \\ Climate Research Division, Scripps Institution of Oceanography, University of California, San Diego, and Water Resources Division, \\ U.S. Geological Survey, La Jolla, California

\section{Michael D. DetTinger} \\ Water Resources Division, U.S. Geological Survey, and Climate Research Division, Scripps Institution of Oceanography, \\ University of California, San Diego, La Jolla, California
}

(Manuscript received 23 February 2004, in final form 12 July 2004)

\section{ABSTRACT}

\begin{abstract}
The variability (1990-2002) of potential evapotranspiration estimates (ETo) and related meteorological variables from a set of stations from the California Irrigation Management System (CIMIS) is studied. Data from the National Climatic Data Center (NCDC) and from the Department of Energy from 1950 to 2001 were used to validate the results. The objective is to determine the characteristics of climatological ETo and to identify factors controlling its variability (including associated atmospheric circulations). Daily ETo anomalies are strongly correlated with net radiation $\left(R_{n}\right)$ anomalies, relative humidity $(\mathrm{RH})$, and cloud cover, and less with average daily temperature $\left(T_{\text {avg }}\right)$. The highest intraseasonal variability of ETo daily anomalies occurs during the spring, mainly caused by anomalies below the high ETo seasonal values during cloudy days. A characteristic circulation pattern is associated with anomalies of ETo and its driving meteorological inputs, $R_{n}, \mathrm{RH}$, and $T_{\text {avg }}$, at daily to seasonal time scales. This circulation pattern is dominated by $700-\mathrm{hPa}$ geopotential height $\left(Z_{700}\right)$ anomalies over a region off the west coast of North America, approximately between $32^{\circ}$ and $44^{\circ}$ latitude, referred to as the California Pressure Anomaly (CPA). High cloudiness and lower than normal ETo are associated with the lowheight (pressure) phase of the CPA pattern. Higher than normal ETo anomalies are associated with clear skies maintained through anomalously high $Z_{700}$ anomalies offshore of the North American coast. Spring CPA, cloudiness, maximum temperature $\left(T_{\max }\right)$, pan evaporation $\left(E_{\mathrm{pan}}\right)$, and ETo conditions have not trended significantly or consistently during the second half of the twentieth century in California. Because it is not known how cloud cover and humidity will respond to climate change, the response of ETo in California to increased greenhousegas concentrations is essentially unknown; however, to retain the levels of ETo in the current climate, a decline of $R_{n}$ by about $6 \%$ would be required to compensate for a warming of $+3^{\circ} \mathrm{C}$.
\end{abstract}

\section{Introduction}

Potential evapotranspiration (ETo) is the atmospheric demand for water from soil and free water surfaces (Rind et al. 1990). As it is estimated from the energy available for the vaporization of water, ETo is a potential rate, with no regard for the actual availability of water to evaporate. As a result, ETo represents an upper bound on actual evapotranspiration (ETa) rates. In California's Central Valley, the average ratios of ETa/ETo range from $1.5 \%$ during the summer to $100 \%$ during the winter $(\mathrm{N}$. Knowles, U.S. Geological Survey, 2003, personal com-

Corresponding author address: Dr. Hugo G. Hidalgo, Climate Research Division, Scripps Institution of Oceanography, 9500 Gilman Drive, MC 0224, La Jolla, CA 92093.

E-mail: hhidalgo@ucsd.edu munication). In many cases, however, estimates of the potential rate can be as useful as the actual rate (Rind et al. 1990). For example, the long-term difference (or ratio) between ETo and precipitation $(P)$ has been considered a measure of aridity used in several climate classification schemes (Koppen 1936; Thornthwaite 1948; Prentice 1990). Climatological aridity is a critical environmental factor that helps to determine the character and sustainability of natural vegetation and terrestrial ecosystems, and consequently is related to erosivity, water demands, and the condition of water resources. The variation of this difference (or ratio) is also an index of drought (Rind et al. 1990). According to a recent modeling study, anthropogenic climate change may soon yield increases in the frequency and severity of droughts and the expansion of deserts (Manabe et al. 2004). These changes would have profound impacts in 
water resources, ecosystems, and socioeconomic structures. Thus, study of changes and covariations of ETo and $P$ are needed and may provide the basis for early warnings of such changes.

Probably the most common practical use of ETo estimates is in scheduling irrigation in agricultural regions (ITRC 2003). On farmed land, the amount of water that has to be applied to the soil (water demand) generally must be close to the potential evapotranspiration rate. Under California's Mediterranean climate, ETo rates reach their maxima during summer months and are low during the winter, while $P$ is largely restricted to winter and spring. Importantly, in California, a large fraction of the winter precipitation is locked as snow in the high elevations until spring and summer so that the largest demands for irrigation water (in the lowlands of the Central Valley) are supplied by spring snowmelt that arrives "just in time." This arrangement is crucial to the success of many of the state's water supply systems, but also imposes challenges to managers of water resources as the supplies and demands vary from year to year. In this study, we investigate the climatic influences on one of the major demands, the demand for irrigation water.

A better understanding of the climatic processes associated with ETo variability is also needed for the improvement of hydrologic models. Climatic mechanisms related to the variability of ETo may provide insight needed to close regional water and energy budgets, to assess influences of changing land surface conditions, and to anticipate changing demands on water supply systems at a variety of time scales.

In the present study, daily, seasonal, and longer-term variations of ETo and of estimated associated meteorological variables are evaluated. In addition, these variations are related to large-scale climatic forcings by comparing them with atmospheric circulation patterns at the $700-\mathrm{hPa}$ pressure level, and to meteorological observations including cloudiness, humidity, temperature, and wind speed. Identifying the primary atmospheric mechanisms responsible for ETo variation in California should help to understand how evaporation demand will be affected by climate variability and climate change.

\section{Data}

\section{a. Meteorological records}

California's strong agricultural economy (especially in the Central Valley) justified the establishment of an automated network of meteorological stations to estimate ETo for irrigation scheduling. The resulting California Irrigation Management Information System (CIMIS; see Web site online at http://www.cimis. water.ca.gov, hereafter referred to as CIMIS Web site) was established in 1982 and is currently managed by the California Department of Water Resources. Data

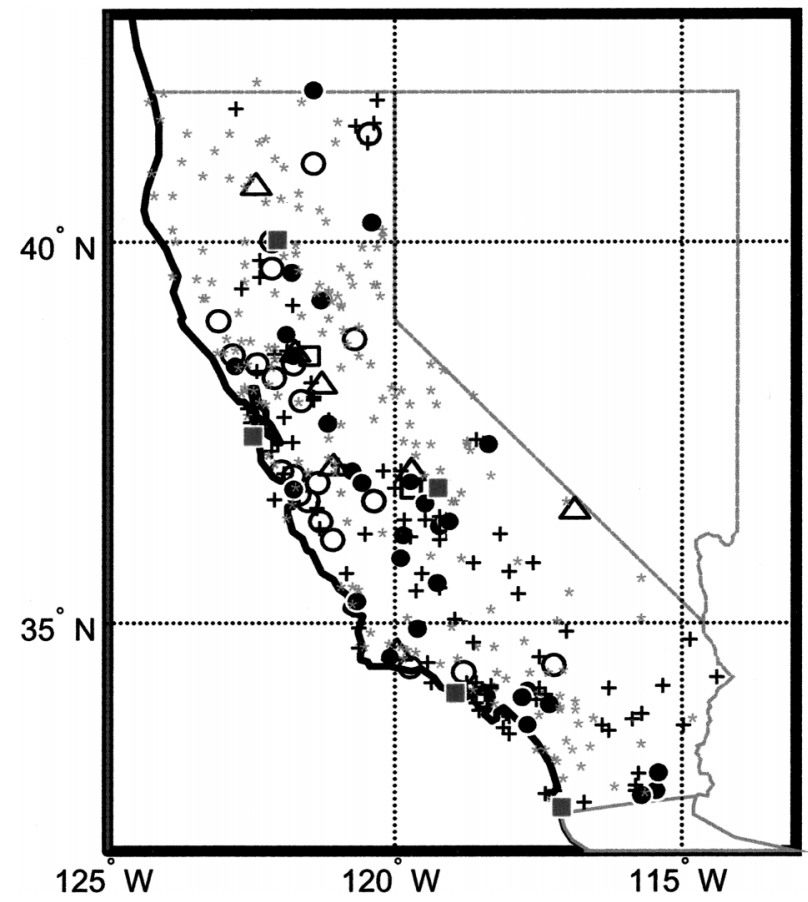

FIG. 1. Location of CIMIS stations with available meteorological data from 1995 to 2002 (open circles), CIMIS stations with available meteorological data from 1990 to 2002 (filled circles), NCDC stations with available daily cloud-cover data from 1984 to 1994 (square markers), DOE stations with monthly cloud-cover data from 1893 to 1995 (solid squares), NCDC stations with available pan evaporation data from 1965 to 2001 (triangle markers), and NCDC stations with precipitation, maximum temperature, and minimum temperature from 1950 to 2001 (plus symbols).

from CIMIS are primarily being used to support agricultural activities throughout the state. However, now that more than 20 years of CIMIS data have been collected, the network's high spatial density makes it useful for climate analyses. To date, CIMIS data have been used in published studies with the objective of calibrating models to predict pasture growth rates (Lile and George 1993) and for evaluating the suitability of empirical ETo equations based on air temperature (Hope and Evans 1992; Hargreaves and Allen 2003; Alexandris and Kerkides 2003). The regional ETo signals contained in these data and the climate patterns that determine that signal have not been investigated previously.

Meteorological variables measured at CIMIS stations include solar radiation, air temperature, soil temperature, humidity, wind speed, and wind direction. The variables are used to estimate hourly ETo rates at CIMIS sites, using a modified Penman equation (see next section; Penman 1948; Pruitt and Doorenbos 1977; CIMIS Web site), and those rates are integrated into daily and monthly values. For this study, daily ETo estimates, together with daily values of net radiation $\left(R_{n}\right)$, mean air temperature $\left(T_{\text {avg }}\right)$, relative humidity $(\mathrm{RH})$, wind speed $\left(U_{\text {avg }}\right)$, and wind direction $\left(U_{\text {dir }}\right)$, were obtained from 52 of the CIMIS stations (Fig. 1). These sites used 
are the subset of the CIMIS network stations that had less than $7 \%$ missing data from 1995 to 2002 . In several analyses, a smaller subset of 29 stations with data spanning the period from 1990 to 2002 were used to capture a broader sampling of ETo variations (Fig. 1). Missing data were filled by averaging neighboring data values, and the resulting time series were detrended and visually inspected for outliers. The mean seasonal cycles of each variable were estimated from 30-day moving averages of period-of-record medians for each day of the calendar year, and the resulting smoothed seasonal cycles were subtracted from all daily variables to obtain daily anomalies. The daily anomalies are used in several of the subsequent analyses. Trends were computed using linear regression applied to the seasonal means of the raw data.

Daily gridded $\left(2.5^{\circ} \times 2.5^{\circ}\right)$ geopotential heights of the $700-\mathrm{hPa}$ pressure level $\left(Z_{700}\right)$, from the National Centers for Environmental Prediction-National Center for Atmospheric Research (NCEP-NCAR) reanalysis (Kalnay et al. 1996; Kistler et al. 2001), were used to characterize atmospheric circulations from 1950 to 2002. The daily $Z_{700}$ were deseasonalized following the same procedure as the CIMIS data. Gridded daily cloudcover fractions, and monthly mean values of surface relative humidity, surface temperature, precipitation rate, and outgoing longwave radiation (OLR; a proxy for cloudiness) from the same time period and same source were used to characterize large-scale processes affecting California's surface variables. El Niño-Southern Oscillation (ENSO) indices, obtained from the archives of the Joint Institute for the Study of the Atmosphere and the Ocean, are used to determine possible ENSO influences on ETo variations.

Hourly cloud-cover observations from 1984 to 1994 at two Central Valley weather stations were obtained from the National Climatic Data Center (NCDC) (Fig. 1). Cloud-cover observations from 6:00 A.M. to 6:00 P.M. each day were averaged to produce daytime means, since inspection of hourly data showed insignificant nighttime contributions to the daily ETo totals. In addition, monthly mean cloud cover data for stations in San Diego, Los Angeles, Fresno, Red Bluff, and San Francisco from 1893 to 1987 were obtained from the Department of Energy (DOE) Carbon Dioxide Information Analysis Center (Steurer and Karl 2004). However, only the cloud-cover data from 1950 to 1987 were used, because changes in cloud-observing practices in the 1930s and 1940s may have introduced spurious trends (Karl and Steurer 1990). These data were used to verify long-term trends in cloud cover. The strength and position of the North Pacific high (NPH) were characterized using the indices described in Hameed et al. (1995). Daily pan evaporation $\left(E_{\mathrm{pan}}\right)$ rates at seven California stations, from 1965 to 2001, were also obtained from NCDC. The $E_{\text {pan }}$ data were used as a check on the CIMIS ETo estimates and to verify the regional climatic patterns that are found to be associated with ETo in this study. Daily precipitation and daily maximum and min- imum temperatures, from 1950 to 2001, at 165 cooperative observer stations in California were obtained from the NCDC and were used to analyze long-term trends. Only stations with less than $7 \%$ of missing data were considered. The data were checked for outliers, and missing data were filled using neighboring values, but no additional manipulation was performed on the data (i.e., tests for homogeneity). A similar dataset, composed of 256 daily precipitation stations covering the same period of the CIMIS data (1990-2000), was also obtained from the Cooperative National Weather Service dataset through NCDC. These data were used to characterize climatological precipitation in high elevations, since most of the CIMIS data and the 165 NCDC meteorological stations previously mentioned are located in lower elevations. Statistics of total population by county for 2002 were obtained from the U.S. Federal Census [see "2002 Data Profiles" on the U.S. Census Bureau Web site (http://www.census.gov/acs/www/ Products/index.htm)]. These data were used to classify the temperature records as coming from either urban or rural stations in order to minimize biases introduced by urbanization (Goodridge 1992).

\section{b. Estimates of ETo}

CIMIS ETo estimates are calculated by applying a modified version of Penman's (1948) equation for a grass reference crop to mean hourly values of net radiation $\left[R_{n_{\text {hour }}}\left(\mathrm{W} \mathrm{m}^{-2}\right)\right]$, relative humidity $\left[\mathrm{RH}_{\text {hour }}(\%)\right]$, mean 2-m air temperature $\left[T_{\text {hour }}\left({ }^{\circ} \mathrm{C}\right)\right]$, and wind speed $\left[U_{\text {hour }}\left(\mathrm{m} \mathrm{s}^{-1}\right)\right]$. The hourly estimates are then aggregated into daily ETo totals. With the exception of $R_{n_{\text {hour }}}$, all of these variables are measured at each CIMIS site. Net radiation $R_{n_{\text {hour }}}$ is estimated from an empirical fit of measured (pyranometer) solar radiation, $T_{\text {hour }}$ and $\mathrm{RH}_{\text {hour }}$, as well as other solar and cloud parameters [Eq. (9); Dong et al. 1992; Monteith 1973]. Net radiation $R_{n_{\text {hour }}}$ is then converted from units of watts per meter squared to millimeters per hour using the latent heat of vaporization according to Eq. (10). The CIMIS version of the Penman hourly evapotranspiration $\left(\mathrm{ETo}_{\text {hour }}\right)$ equation is (Penman 1948; Pruitt and Doorenbos 1977; Dong et al. 1992; Satterlund 1979; Monteith 1973; CIMIS Web site)

$$
\begin{gathered}
\mathrm{ETo}_{\text {hour }}=\frac{\Delta}{\Delta+\gamma} R_{n_{\text {hour }}}+\left(1-\frac{\Delta}{\Delta+\gamma}\right)\left(e_{s}-e_{a}\right) f_{U} \\
\left(\mathrm{~mm} \mathrm{~h}^{-1}\right)
\end{gathered}
$$

where

$$
\begin{aligned}
\Delta & =\frac{4099 e_{s}}{\left(T_{\text {hour }}+237.3\right)^{2}}\left(\mathrm{kPa}^{\circ} \mathrm{C}^{-1}\right), \\
\gamma & =\frac{P_{\mathrm{atm}} c_{p}}{\lambda \varepsilon}\left(\mathrm{kPa}{ }^{\circ} \mathrm{C}^{-1}\right), \\
P_{\mathrm{atm}} & =101.3-0.0115 z+5.44 \times 10^{-7} z^{2}
\end{aligned}
$$$$
(\mathrm{kPa}) \text {, }
$$ 


$$
\begin{aligned}
& \lambda=\left(2.50-0.0022 T_{\text {hour }}\right)\left(\mathrm{MJ} \mathrm{kg}^{-1}\right), \\
& e_{s}=0.6108 \exp \left(\frac{T_{\text {hour }} 17.27}{T_{\text {hour }}+237.3}\right)(\mathrm{kPa}), \\
& e_{a}=\frac{\mathrm{RH}_{\text {hour }}}{100} e_{s}(\mathrm{kPa}) \\
& \text { if } R_{n_{\text {hour }}} \leq 0 \text { : } \\
& f_{U}=0.125+0.0439 U_{\text {hour }}\left(\mathrm{mm} \mathrm{h}^{-1} \mathrm{kPa}^{-1}\right), \\
& \text { if } R_{n_{\text {hour }}}>0 \text { : } \\
& f_{U}=0.030+0.0576 U_{\text {hour }}\left(\mathrm{mm} \mathrm{h}^{-1} \mathrm{kPa}^{-1}\right), \\
& R_{n_{\text {hour }}}^{\left(\mathrm{W} \mathrm{m}^{-2}\right)}=0.89\left\{(1-\alpha) \mathrm{Rs}+\sigma\left(T_{\text {hour }}+273.15\right)^{4}\right. \\
& \left.\times\left[\varepsilon_{a}(O)(1-c)+c-0.98\right]\right\} \\
& \left(\mathrm{W} \mathrm{m}^{-2}\right) \text {, } \\
& R_{n_{\text {hour }}}^{\left(\mathrm{mm} \mathrm{h}^{-1}\right)}=\frac{R_{n_{\text {hour }}}^{\left(\mathrm{W} \mathrm{m}^{-2}\right)}}{277.78 \lambda}\left(\mathrm{mm} \mathrm{h}^{-1}\right), \\
& \text { if } \frac{\mathrm{Rs}}{I} \geq 0.375 \text { : } \\
& \alpha=0.00158 \Theta+0.386 \exp (-0.0188 \Theta), \\
& \text { if } \frac{\mathrm{Rs}}{I}<0.375 \text { : } \\
& \alpha=0.26 \text {, } \\
& I=I_{o} \cos (\mathrm{Z})\left(\mathrm{W} \mathrm{m}^{-2}\right) \text {, } \\
& Z=90-\Theta \text { (degrees), } \\
& \varepsilon_{a}(O)=1.08\left\{1-\exp \left[-\left(10 e_{a}\right)^{\left(T_{\text {hour }}+273.15\right) / 2016}\right]\right\}, \\
& c=\left(1.33-1.33 \frac{\mathrm{Rs}}{\mathrm{Ra}}\right)^{0.294}, \\
& \text { if } c>1: \quad c=1 \text {, } \\
& \text { if } c<0: \quad c=0 \text {, } \\
& \mathrm{Ra}=\left(0.79-\frac{375}{\Theta}\right) I\left(\mathrm{~W} \mathrm{~m}^{-2}\right),
\end{aligned}
$$

where $\Delta$ is the slope of the Clausius-Clapeyron equation relating saturation vapor pressure to temperature, $\gamma$ is the psychometric constant, $e_{s}$ is the saturation vapor pressure, $e_{a}$ is the actual vapor pressure, $c_{p}$ is the specific heat at constant pressure $\left(1.013 \times 10^{-3} \mathrm{MJ} \mathrm{kg}^{-1}{ }^{\circ} \mathrm{C}^{-1}\right)$, $\varepsilon$ is the ratio of the molecular weight of water vapor to that of dry air (0.622), and $P_{\text {atm }}$ is the barometric pressure, estimated from the station elevation $z(\mathrm{~m})$ using Eq. (4). Equation (8) is an empirical wind function that was developed by the University of California (CIMIS Web site) to estimate the influence of winds on ETo.

Details of the formulations leading to Eqs. (9) and (11)-(16) can be found in Dong et al. (1992). In these equations, $\alpha$ is the surface albedo over well-watered grass, $\mathrm{Rs}\left(\mathrm{W} \mathrm{m}^{-2}\right)$ is the measured solar radiation received at a horizontal plane at each CIMIS station, $\sigma$ is the Stefan-Boltzman constant $\left(5.670 \times 10^{-8} \mathrm{~J} \mathrm{~K}^{-4}\right.$ $\left.\mathrm{m}^{-2} \mathrm{~s}^{-1}\right), \varepsilon_{a}(O)$ is the clear-sky emissivity [Eq. (14); Satterlund 1979], $I\left(\mathrm{~W} \mathrm{~m}^{-2}\right)$ is the irradiance on a horizontal surface at the top of the atmosphere, $I_{o}$ is the solar constant $\left(1367 \mathrm{~W} \mathrm{~m}^{-2}\right), c$ is the fractional cloud cover $(0 \geq c \leq 1)$ estimated from Eq. (15), $\Theta$ (degrees) is the solar altitude, $Z$ (degrees) is the zenith angle [Eq. (13)], and $\mathrm{Ra}\left(\mathrm{W} \mathrm{m}^{-2}\right)$ is the potential clear-sky solar radiation [Eq. (16)].

Potential evapotranspiration ETo formulations based on the Penman equation sometimes consider a measured or estimated ground heat flux $(G)$, which is subtracted from $R_{n}$, in order to account for heat transference at the air-soil interface (Monteith 1965). In order to determine if CIMIS's ETo estimates would be affected significantly by the exchange of heat with the soil, $G$ was approximated using Eq. (17) (Shuttleworth 1993; van Wijk and de Vries 1963), which is based on the day-to-day difference of soil temperatures $\left[\right.$ Tsoil $\left.\left({ }^{\circ} \mathrm{C}\right)\right]$ :

$$
G_{\text {day } 1}=\frac{0.38}{\lambda}\left(\text { Tsoil }_{\text {day } 2}-\text { Tsoil }_{\text {day1 }}\right)\left(\mathrm{mm} \mathrm{day}^{-1}\right) \text {. }
$$

Equation (17) is intended for estimating $G$ at daily time scales for average soil conditions and properties. Since the CIMIS data is based on hourly ETo estimates, alternative ETo estimates based on Eq. (1) were computed using daily mean values of $R_{n}, \mathrm{RH}, U$, and $T_{\text {avg }}$. The daily anomalies of these alternative estimates proved to be strongly correlated (median correlation $=0.84, p<$ 0.01 ) with the values reported by CIMIS (which were computed at hourly time scales and integrated into daily values). These correlations did not change significantly when $G$ was included (median correlation $=0.83, p<$ $0.01)$. Although there are a few exceptional days when $G$ becomes an important fraction of ETo (greater than $10 \%$ ), the median contribution of $G$ is less than $0.1 \%$ of ETo for the set of California stations used here. Other correlations, such as the ones between ETo and $E_{\mathrm{pan}}$ anomalies did not change significantly (less than \pm 0.02 change) when the $G$ term was added. Therefore, the ground flux is not included in subsequent analyses, which are instead based on the standard ETo estimates reported by CIMIS.

CIMIS ETo estimates and nearby pan evaporation station data $\left(E_{\mathrm{pan}}\right)$ are well correlated at monthly scales (Table 1; see also Grismer et al. 2002). However, the $E_{\text {pan }}$ rates are usually higher than their corresponding ETo estimates. The evaporation from a pan can vary significantly from the surrounding vegetation (even well-watered) or nearby lakes. This difference is usually accounted through pan coefficients $\left(k_{\mathrm{pan}}\right)$ such that

$$
\text { ETo }=k_{\mathrm{pan}} E_{\mathrm{pan}}\left(\mathrm{mm} \mathrm{day}^{-1}\right) .
$$

Pan coefficients are usually less than one, but they vary widely according to pan characteristics, $U, \mathrm{RH}$, and the length of upwind fetch of green crop (Shuttleworth 


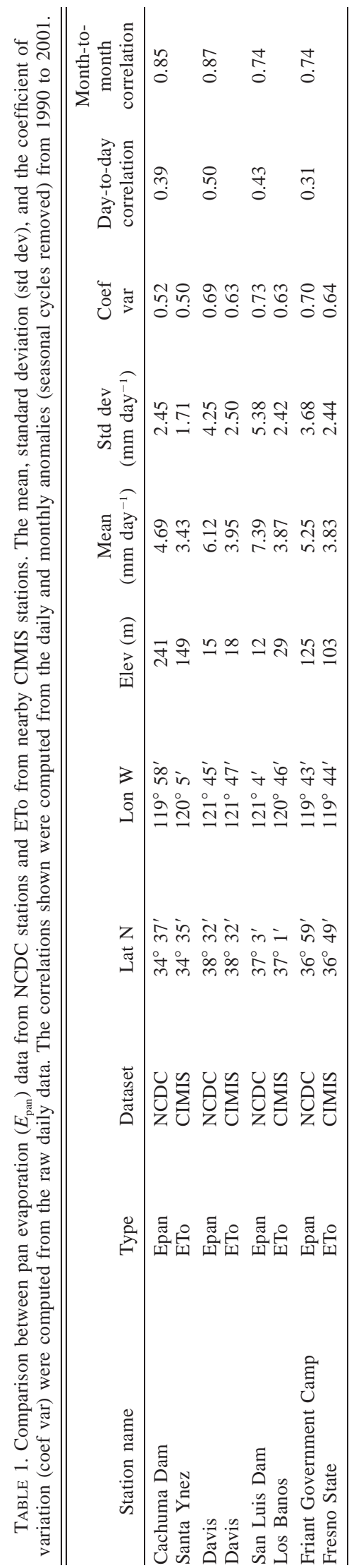

TABLE 2. Mean, standard deviation, and coefficients of variation of ETo and $P$ water year totals (Oct-Nov) from California stations from 1990 to 2001 . The ETo and $P_{\text {Cimis }}$ values shown represent the median of 29 CIMIS stations shown as filled circles in Fig. 1. The $P_{\mathrm{NCDC}}$ correspond to the median values for 256 stations shown with a "+" and "*" symbols in Fig. 1.

\begin{tabular}{lccc}
\hline \hline & ETo & $P_{\text {CIMIs }}$ & $P_{\text {NCDC }}$ \\
\hline Mean $(\mathrm{mm})$ & 1344 & 321 & 971 \\
Std dev $(\mathrm{mm})$ & 70 & 152 & 443 \\
Coef var & 0.05 & 0.48 & 0.44 \\
\hline
\end{tabular}

1993). Daily $E_{\mathrm{pan}}$ anomalies have higher standard deviations than ETo anomalies and are only moderately correlated with ETo anomalies, but at monthly time scales Penman ETo estimates seem to be significantly correlated with $E_{\text {pan }}$ data (Table 1). Similar results have been found in other regions of the world (Chiew and McMahon 1992; Xu and Singh 1998). There are many reasons why potential evaporation estimates from the Penman equation $\left(E_{\mathrm{pen}}\right)$ would differ from the pan data estimations even when some limitations of the Penman and pan methods are considered. One of the most obvious differences is that $E_{\mathrm{pan}}$ and $E_{\mathrm{pen}}$ are based on data collected from different evaporating surfaces (soil versus water). The roughness and the exchange of energy of the air with water and soil surfaces are different. In addition, if the soil is not kept continuously saturated, the water from deeper layers has to be drawn through capillarity until pores with the lower matric potential are depleted (Lee 1980). It is unfortunate that ETo could not be further validated as there are almost no data available in California from other methods such as lysimeter, Bowen ratio, or eddy covariance.

\section{Variability of ETo and related observations}

\section{a. Climatology and seasonality}

Annual ETo totals in California are greater than annual precipitation, a relation that is characteristic of its semiarid climate. When only the CIMIS stations are considered, precipitation is on average only $24 \%$ of annual ETo (Table 2). However, the average annual precipitation for California computed from CIMIS stations is underestimated, as there are only a few stations in the high-producing areas in the high elevations. Considering the contribution of a larger range of elevations contained in 256 NCDC stations, precipitation in California is on average $72 \%$ of ETo annual totals (Table 2 ). There is, however, large spatial variability in the distribution of the water deficit. The average (19902002) water deficit (ETo minus $P$ ) ranges from approximately $200 \mathrm{~mm} \mathrm{yr}^{-1}$ at northern coastal sites to more than $1800 \mathrm{~mm} \mathrm{yr}^{-1}$ in the southern deserts (Fig. 2); $P$ is also much more variable from year to year than ETo. The coefficient of variation of annual $P$ is on the order of $40 \%$, while that for ETo is only 5\% (Table 2). Throughout the network, ETo reaches its maximum in 


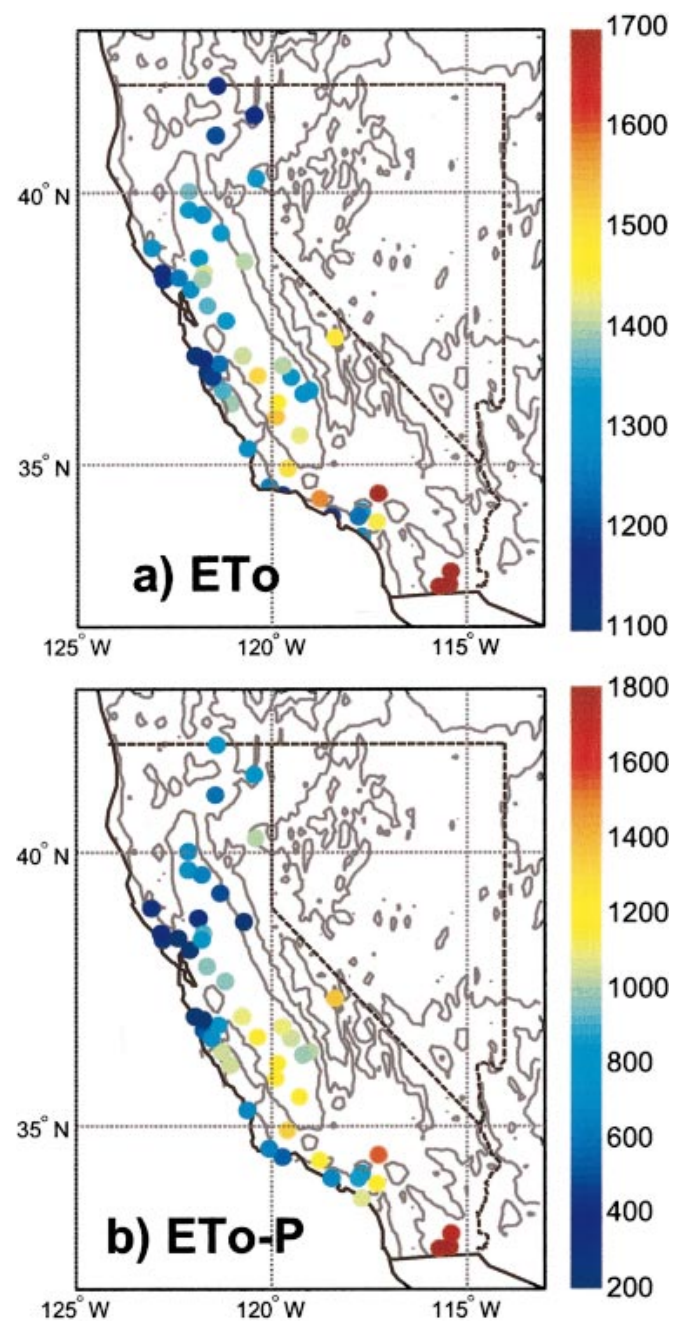

FIG. 2. Average annual total (a) ETo and (b) ETo $-P\left(\mathrm{~mm} \mathrm{yr}^{-1}\right)$ from 1995 to 2002 . Contours are every $1000 \mathrm{~m}$ starting at $500-\mathrm{m}$ elevation.

July or August during the dry summer season when clouds are few, insolation is long and intense, and temperatures are high. The seasonal minimum of ETo is in January, during the wet (cloudy and cool) winters (Fig. 3); $P$ and ETo are thus modulated by conditions in distinctly different, evidently independent seasons.

California's precipitation is episodic and provided mostly by relatively few winter storms each year. In contrast, ETo is more persistent and seasonal in character, although significant anomalies around the seasonal cycle occur. The daily ETo anomalies are characterized by some extremely low values (Fig. 4). The majority of these negative anomalies extend from the winter through the spring until the midsummer (Fig. 4), and they are infrequent for the rest of the summer. As will be seen in following sections, these extremely negative daily ETo anomalies are associated with cloudy days during the spring. Anomalies of ETo are more persistent than $P$ anomalies at daily time scales, but, on

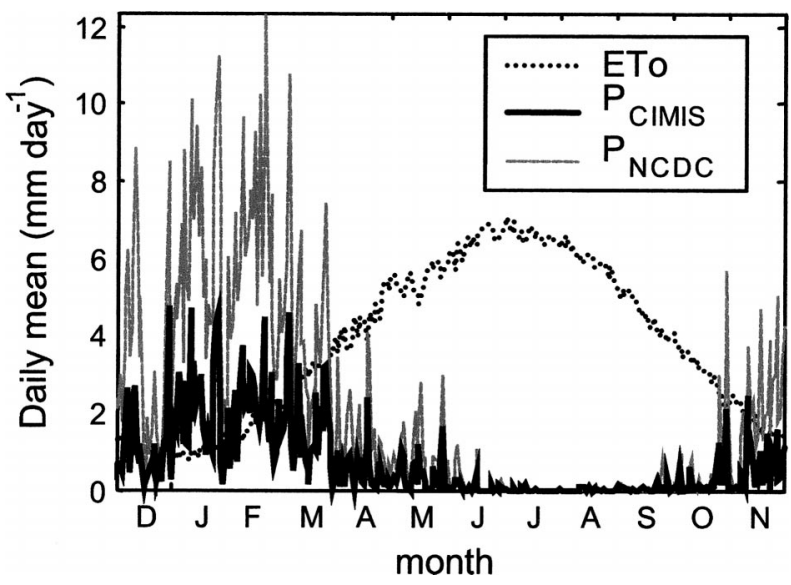

FIG. 3. Median daily averages of ETo (dotted line), $P$ from CIMIS station (thick solid line), and $P$ from NCDC stations (thin solid line) in $\mathrm{mm} \mathrm{day}^{-1}$.

the monthly scale, the lag 1 autocorrelation coefficients of ETo and $P$ are similar, suggesting comparable memories (Table 3). ETo rates are relatively low in winter and autumn, and summer ETo values-although largest overall-are relatively least variable. The median spring standard deviation of the daily ETo anomalies is 1.36 $\mathrm{mm}$ day $^{-1}$, and for summer is $0.89 \mathrm{~mm} \mathrm{day}^{-1}$. Spring ETo is both large and highly variable. Consequently, the rest of this paper tends to focus on the warm season and, especially, spring ETo variations.

The amplitude of the seasonal cycles of ETo, as well
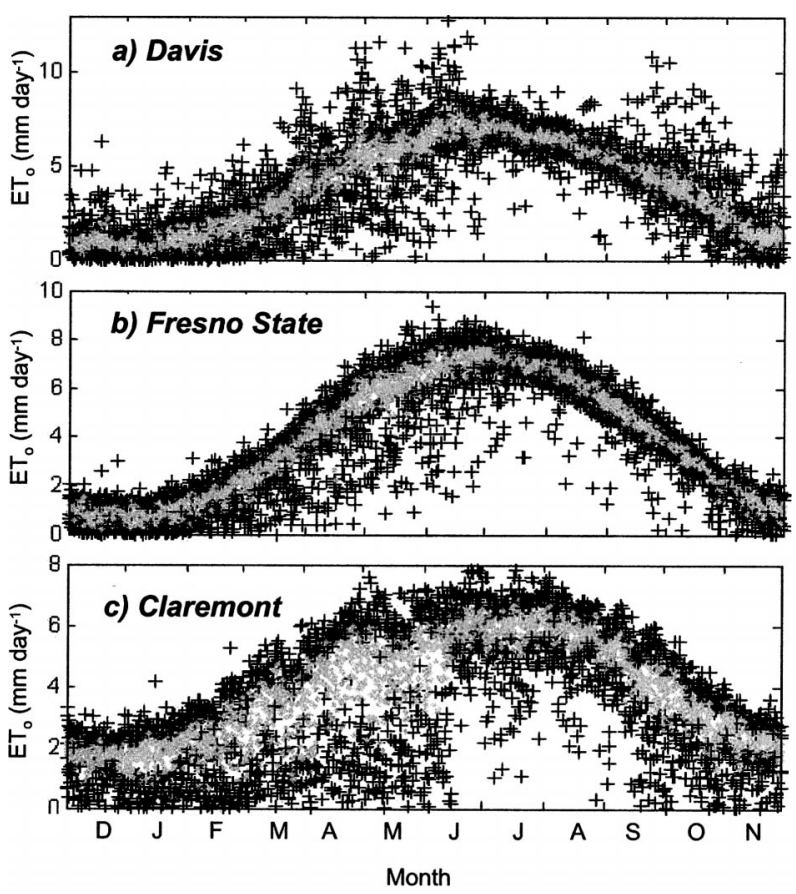

FIG. 4. Distributions of the daily ETo data from 1995 to 2002 for selected CIMIS stations; ETo values inside (outside) the interquartile range are shown with a light dot (dark plus) symbol. 
TABLE 3. Median lag-1 autocorrelation coefficient $\left(\rho_{1}\right)$ of ETo and $P$ anomalies and coefficient of variation (c.v.) obtained by dividing the std dev of the ETo and $P$ anomalies by the mean of their actual values. The values represent the median of 29 CIMIS stations from 1990 to 2002

\begin{tabular}{lrrrrr}
\hline \hline & \multicolumn{2}{c}{ ETo } & & \multicolumn{2}{c}{$P$} \\
\cline { 2 - 3 } \cline { 5 - 6 } & $\rho_{1}$ & c.v. & & $\rho_{1}$ & c.v. \\
\hline Daily & 0.55 & 0.25 & & 0.27 & 4.82 \\
5 days & 0.37 & 0.18 & & 0.27 & 2.85 \\
10 days & 0.31 & 0.15 & & 0.27 & 2.21 \\
30 days & 0.32 & 0.11 & & 0.33 & 1.56 \\
90 days & 0.23 & 0.08 & & 0.03 & 1.13 \\
Annual & -0.02 & 0.05 & & -0.23 & 0.47 \\
\hline
\end{tabular}

as of the other CIMIS variables (except the wind parameters), is strongly modulated by the strength of the influence of North Pacific air masses, which are roughly proportional to the distance from the ocean. For example, the difference between daily ETo from summer to winter ranges from $3.3 \mathrm{~mm} \mathrm{day}^{-1}$ in coastal stations to $7.3 \mathrm{~mm} \mathrm{day}^{-1}$ inland. The moist near-surface air along the coast dampens seasonal cycles in contrast to the semiarid environment farther inland. The logarithm of distance to the coast explains $62 \%$ and $87 \%$ of the spatial variation of the amplitudes of the ETo and $T_{\text {avg }}$ seasonal cycles, respectively, for the 52 CIMIS stations shown in Fig. 1. This modulation of seasonal cycles by the marine environment is stronger among the CIMIS sites than is the influence of elevation. However, the CIMIS network, and the subset of stations used here, is denser in the Central Valley and along the central and southern California coast. The underrepresentation of high altitudes in the CIMIS network may lead to an underemphasis of elevation effects, and the paucity of southern California desert stations probably yields an underemphasis of the role of north-south climate contrasts.

\section{b. Meteorological factors of ETo variability}

Among the CIMIS meteorological variables, at the regional scale considered here, $R_{n}$ and $\mathrm{RH}$ fluctuations contribute most to the variability of daily ETo anomalies. The analysis of this section is based on correlations between the anomalies of ETo and the anomalies of the related variables $\left(R_{n}, T_{\text {avg }}, \mathrm{RH}\right.$, and $\left.U\right)$. It should be noted that when ETo is computed from these related variables, the seasonal cycles are included in the equation. ETo's seasonal cycle can be approximated fairly accurately using the seasonal cycle of $R_{n}$ (or even $T_{\text {avg }}$ ). For this reason, in order to find the origin of the dayto-day ETo anomalies the seasonal cycles were removed from the data. The sense of the correlations of the anomalies of the related variables with ETo are such that positive anomalies of $R_{n}$ (higher than normal solar irradiation) and negative anomalies of RH (drier than normal conditions) are associated with higher than normal ETo anomalies (Table 4a). Wind speed anomalies, $U_{\text {avg }}$,
TABLE 4. Median intercorrelations at different time scales of meteorological variables for 29 CIMIS stations in California from 1990 to 2002 .

\begin{tabular}{lcccrr}
\hline \hline (a) Daily anomalies (intraseasonal variations) & & \\
& ETo & $R_{n}$ & $\mathrm{RH}$ & $T_{\text {avg }}$ & \multicolumn{1}{c}{$U_{\text {avg }}$} \\
\hline ETo & 1.00 & 0.81 & -0.67 & 0.43 & 0.21 \\
$R_{n}$ & & 1.00 & -0.46 & 0.11 & -0.04 \\
RH & & & 1.00 & -0.27 & -0.08 \\
$T_{\text {avg }}$ & & & & 1.00 & 0.00 \\
$U_{\text {avg }}$ & & & & & 1.00
\end{tabular}

(b) Month-to-month (seasonal cycle included)

\begin{tabular}{lcrrrr} 
& ETo & $R_{n}$ & $\mathrm{RH}$ & $T_{\text {avg }}$ & $U_{\text {avg }}$ \\
\hline ETo & 1.00 & 0.99 & -0.75 & 0.92 & 0.56 \\
$R_{n}$ & & 1.00 & -0.69 & 0.89 & 0.55 \\
RH & & & 1.00 & -0.68 & -0.21 \\
$T_{\text {avg }}$ & & & & 1.00 & 0.36 \\
$U_{\text {avg }}$ & & & & & 1.00
\end{tabular}

(c) Year-to-year (interannual variations)

\begin{tabular}{lcccrc} 
& ETo & $R_{n}$ & $\mathrm{RH}$ & \multicolumn{1}{c}{$T_{\text {avg }}$} & $U$ \\
\hline ETo & 1.00 & 0.76 & -0.67 & 0.38 & 0.24 \\
$R_{n}$ & & 1.00 & -0.37 & 0.00 & 0.01 \\
RH & & & 1.00 & -0.23 & 0.10 \\
$T_{\text {avg }}$ & & & & 1.00 & 0.07 \\
$U_{\text {avg }}$ & & & & & 1.00 \\
\hline
\end{tabular}

are poorly correlated with ETo anomalies. For this reason, the results for $U_{\text {avg }}$ are not shown in the following analyses. The $T_{\text {avg }}$ anomalies correlations with ETo anomalies are weaker than the $R_{n}$ anomalies correlations because the terms associated with $T_{\text {avg }}$ in the Penman equation are highly nonlinear. The nonlinear relationship between $T_{\text {avg }}$ and ETo also appears in other temperature-based ETo equations such as the Hargreaves' equation (Hargreaves et al. 1985; Hargreaves and Allen 2003). Physically, this probably reflects the relatively modest excursions of vapor pressure $\left(e_{\text {sat }}\right.$ and $\left.\Delta\right)$ over the range of temperatures encountered in California. The $T_{\text {avg }}$ and $R_{n}$ anomalies are moderately to weakly correlated, indicating that the two variables provide somewhat independent influences on ETo anomalies. At daily time scales, $R_{n}$ anomalies are more linearly related on relative humidity anomalies and other variables, such as cloudiness, than air temperatures.

When the seasonal cycles are included and the highfrequency variations are dampened by integrating the raw data into monthly means, $R_{n}$ and ETo are still the highest intercorrelated variables. However, the correlations between $T_{\text {avg }}$ and ETo (and $T_{\text {avg }}$ and $R_{n}$ ) are also quite strong, suggesting that the seasonal cycles of ETo and $T_{\text {avg }}$ are strongly correlated (Table 4b), although this correlation does not imply causality. In comparison, the seasonal cycles of RH and ETo are not as strongly related. In terms of the interannual variations, $R_{n}$ showed the strongest correlations and RH explains a similar fraction of the variability of ETo as it did at daily time scales. Notably, for interannual time scales, $T_{\text {avg }}$ does not explain a large fraction of the variation of ETo (Table $4 c)$. 


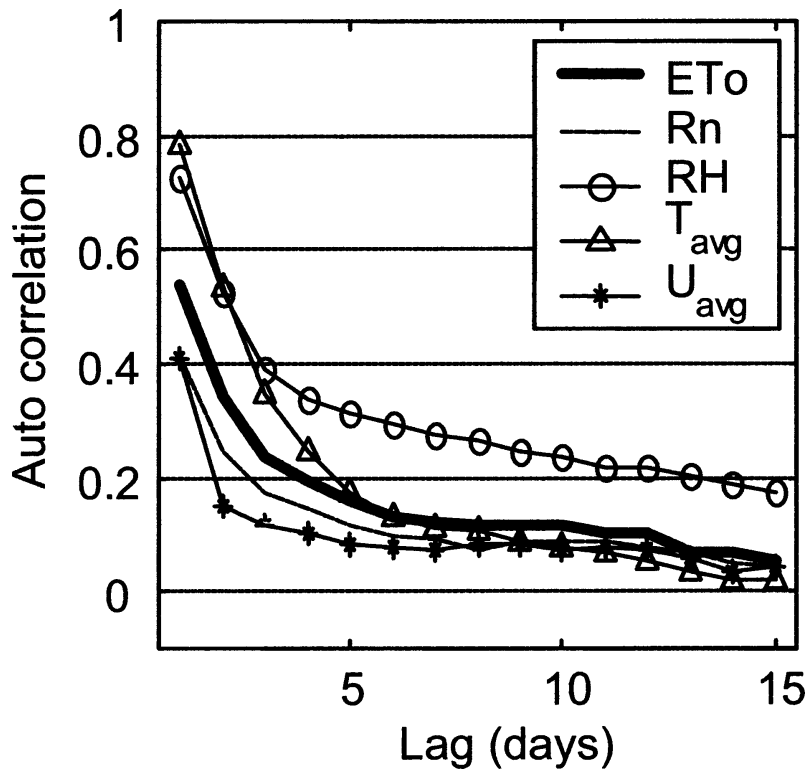

FIG. 5. Median lag autocorrelations of daily warm-season (AprSep) anomalies of different meteorological variables from 29 CIMIS stations (1990-2002).

\section{c. Variability}

The characteristic time scales of daily CIMIS fluctuations differ from variable to variable. Daily variations of ETo are most similar to those of $R_{n}$ (as noted previously) and this similarity is reflected in their characteristic time scales. Daily correlograms of CIMIS variables during the warm season (spring plus summer) are shown in Fig. 5. Variations of both ETo and $R_{n}$ have decorrelated (have $e$-folding times) after about 1 to 2 days, on average, in all seasons. In contrast, $\mathrm{RH}$ and $T_{\text {avg }}$ are most persistent, decorrelating only after about 3 to 4 days. Although the lag correlation for each variable becomes small by about 5 days, each has persistently nonzero values to at least 10 to 12 days (especially $\mathrm{RH})$, reflecting long-term intraseasonal to interseasonal excursions (e.g., some springs are just clearer or warmer than others). After about 8 days most of the high-frequency autocorrelation is low for all variables and is only marginally reduced from this point to 15 or 30 days. The correlogram of RH is fairly similar to $T_{\text {avg }}$ at short lags, albeit with a wider range of variability between stations. Presumably, differences in their decorrelation time scales reflect differences in the process controlling each of these variables. These processes would include the larger-scale atmospheric circulation that strongly governs daily temperature and humidity (larger-scale controls) and smaller-scale cloud processes that govern $R_{n}$ anomalies. After a single day $U_{\text {avg }}$ decorrelates completely and presumably reflects strong short-term influences. As noted previously, ETo reflects a combination of radiation and humidity time scales, with its time scale falling between the two. However, as noted previously, ETo anomalies are most strongly influenced by $R_{n}$, and thus the time scale of its fluctuations around its strong seasonal cycle is quite short.

The amplitudes of daily variations of the CIMIS variables also differ, between variables, seasonally, and geographically. The standard deviations of the daily CIMIS anomalies for ETo, $R_{n}, \mathrm{RH}$, and $T_{\text {avg }}$ are mapped in Fig. 6. Much like the amplitudes of seasonal cycles, the standard deviations of daily $T_{\text {avg }}$ anomalies depend to a considerable extent upon proximity to the coast, with the largest variations at the interior stations, especially in the northeastern corner of California on the lee side of the Sierra Nevada. In contrast, standard deviations of ETo are not strongly related to the distance to the coast. Other factors, such as the variation of cloud cover and other influences (i.e., large-scale circulation), must determine the size of the ETo variations.

Daily variations of ETo, $R_{n}$, and $T_{\text {avg }}$ anomalies are the largest in spring and somewhat smaller during the summer. Winter and autumn variations of ETo and $R_{n}$ anomalies are smallest. The larger ETo variability during the spring reflects a general increase in the standard deviations, but notably much of this spread reflects the occurrence of low values during cloudy days, as the negative anomalies are generally larger in magnitude as the positive anomalies (Fig. 4). These negative anomalies become much less frequent (in some settings quite abruptly) by midsummer. The abrupt transition between the broad spring and narrow summer ETo distributions reflects the rapid reduction of cloudiness once summer circulations are established (Nogues-Paegle and Mo 1987). The tendency toward higher variability during spring parallels, and is largely driven by, a similar tendency in $R_{n}$ at most of the stations. The springtime negative ETo anomalies correspond to $R_{n}$ reductions associated with partially (and completely) cloudy days that interrupt the seasonal progression from cool-season to warm-season ETo norms. The much lower autumn and winter ETo values are only marginally reduced by clouds, and the variability during these seasons is small. Summertime variability of ETo and $R_{n}$ anomalies are small, mostly because clouds are scattered and infrequent throughout the state in this season, especially in the Central Valley (Davis and Fresno State stations in Fig. 4).

As was mentioned before, ETo deviations above the median (positive anomalies) tend to be smaller than are the lower than median excursions (negative anomalies), except for a few stations, mostly in the Sacramento Basin (i.e., Davis in Fig. 4). The episodes of extremely high spring ETo in the Sacramento Basin are associated with combinations of exceptionally clear skies with high temperatures and low RH in the basin. An analysis of weather reports from two Central Valley stations (Fig. 7) reveals that the variation of ETo is inversely correlated with clouds, fog, and rain during the spring, and that the presence of haze does not preclude high ETo. Rainy days during the spring are almost exclusively associated with low ETo days (and high cloudiness), 
SPRING
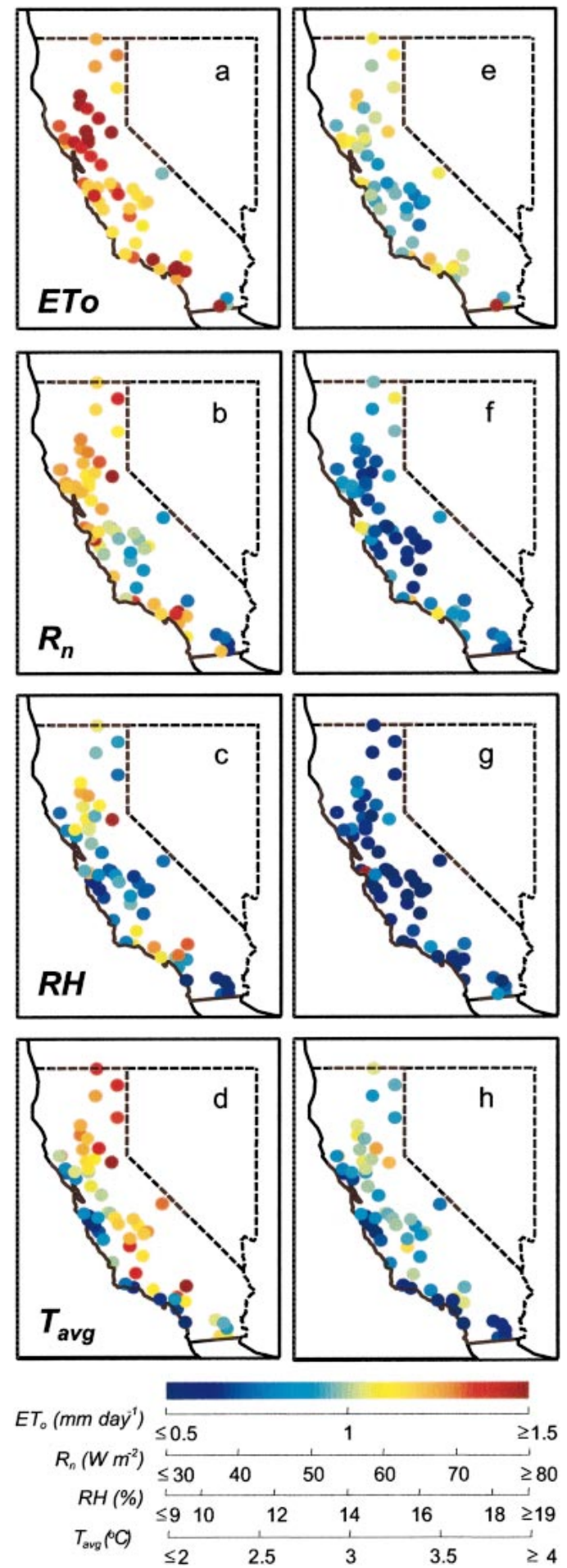

FIG. 6. Std devs of daily anomalies for spring and summer, 1995-2002.

SUMMER
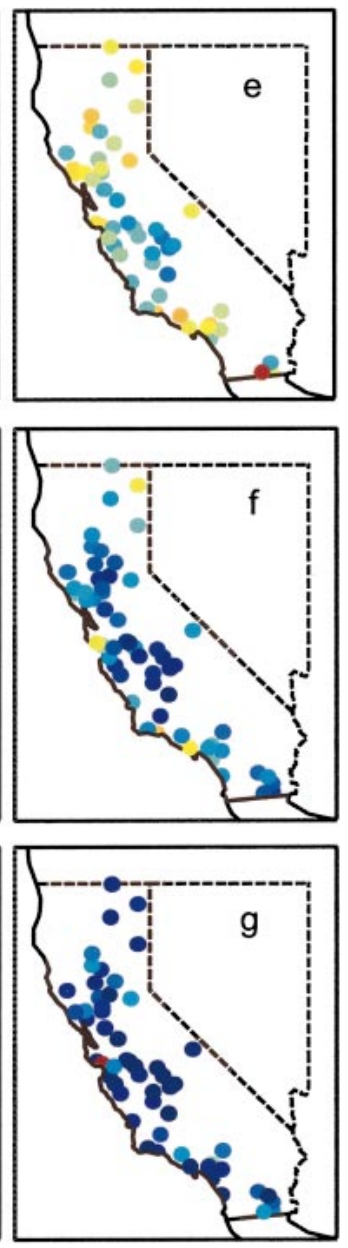

while high ETo days are exclusively related with dry days (and low cloudiness). Normal ETo days are almost always observed in days with no rain but with some amount of cloud coverage.

\section{Influence of large-scale climate \\ a. Regional atmospheric circulation}

Regional atmospheric circulations have strong effects on the variability of CIMIS variables at all time scales, and a single, shared circulation pattern is associated with anomalies of ETo and its driving meteorological inputs, $R_{n}, \mathrm{RH}$, and $T_{\text {avg }}$. The correlations between daily anomalies of $Z_{700}$ and each of these variables are shown in Fig. 8 and reveal a consistent underlying circulation pattern. The correlation pattern that all the variables share is dominated by $Z_{700}$ anomalies over a region off the west coast of North America, approximately between $32^{\circ}$ and $44^{\circ}$ latitude. The pattern is displaced somewhat inland in the $T_{\text {avg }}$ correlations. During the spring, the shape of the $R_{n}$ correlation pattern is very similar to the ETo pattern (Fig. 8), consistent with the strong dependence of ETo and $R_{n}$ (Table 4). The ETo correlation pattern during summer is more similar to the 
SPRING

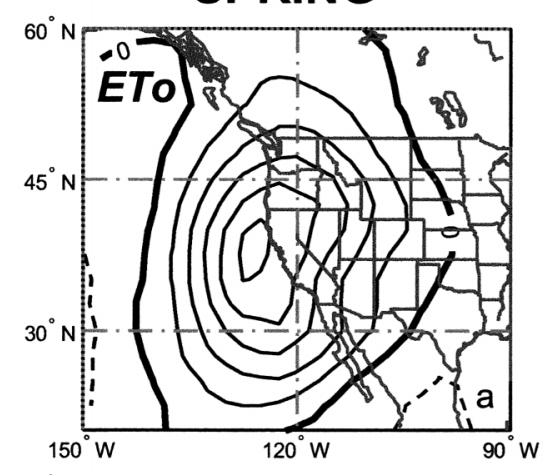

$$
60^{\circ} \mathrm{N}
$$
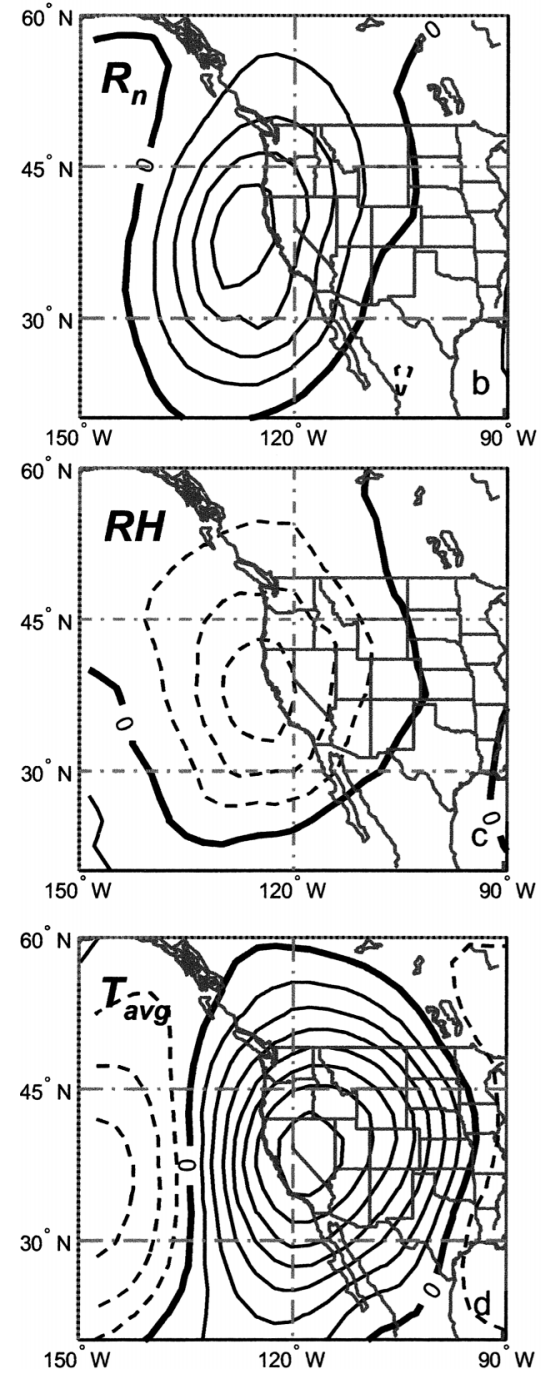

SUMMER
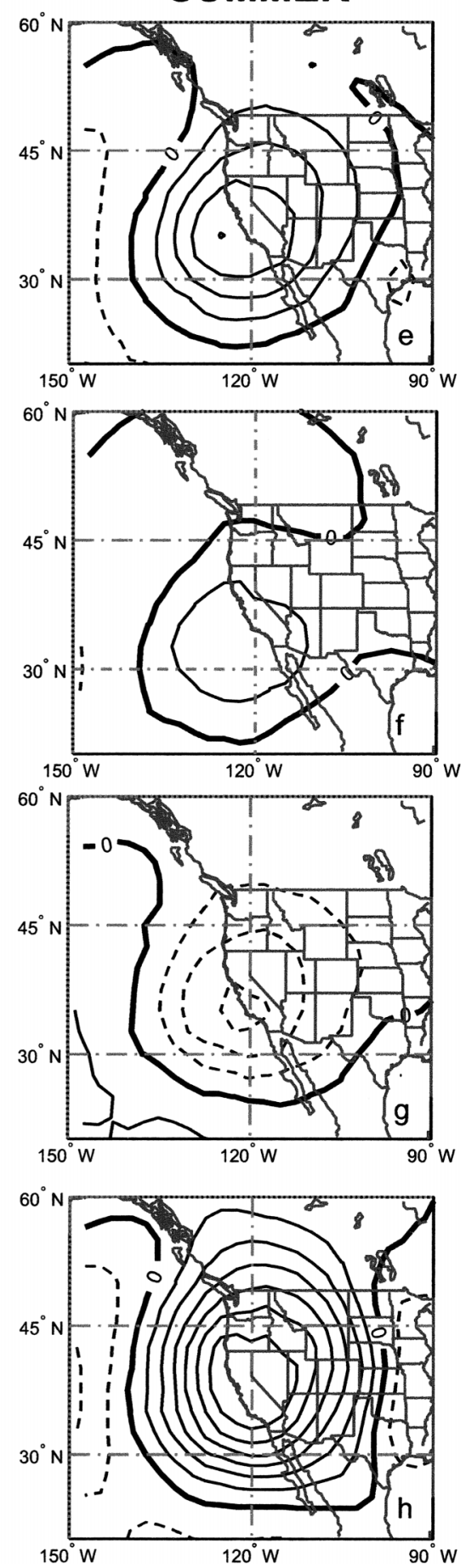

FIG. 8. Median day-to-day correlations between anomalies of several meteorological parameters and anomalies of 700-hPa geopotential height data. The contours represent the median correlation of a subset of 29 CIMIS stations from 1990 to 2002. Contours every 0.10 . Dashed (solid) lines were used for negative (positive) correlations. Zero contour (thick line) is labeled. 
$\mathbf{Z}_{700}$ and total cloud cover
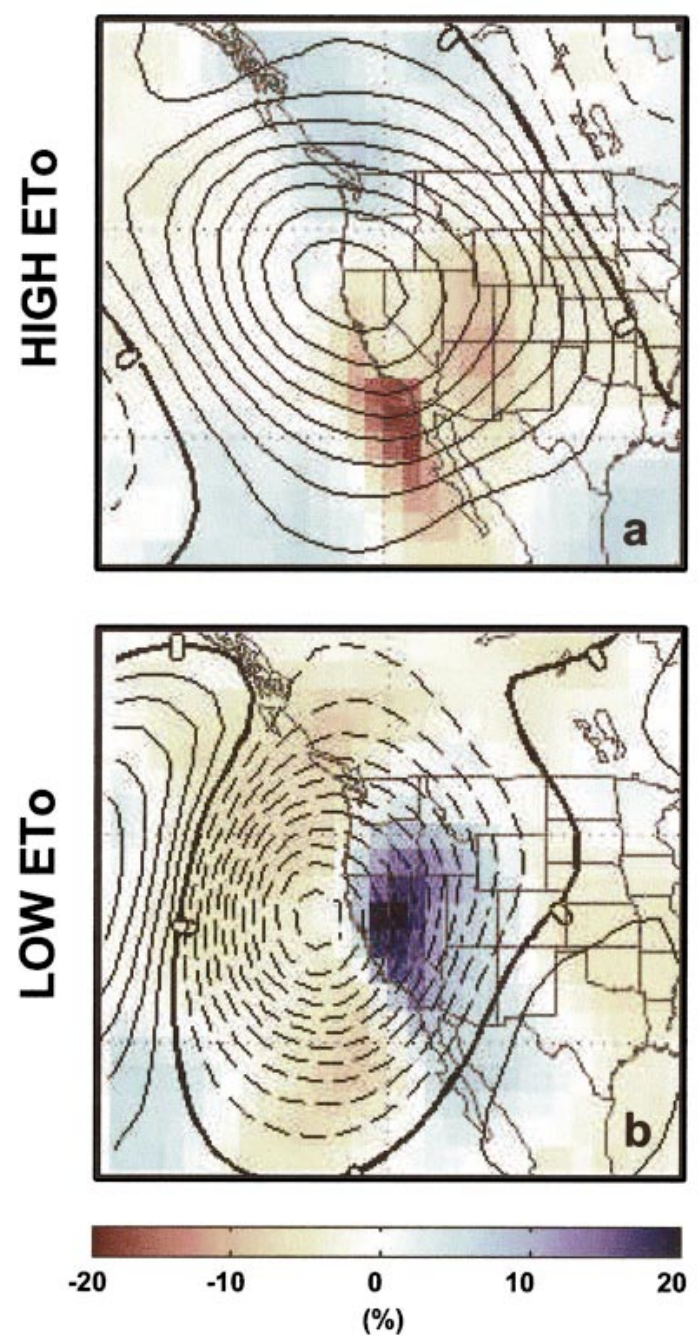

Wind speed and direction
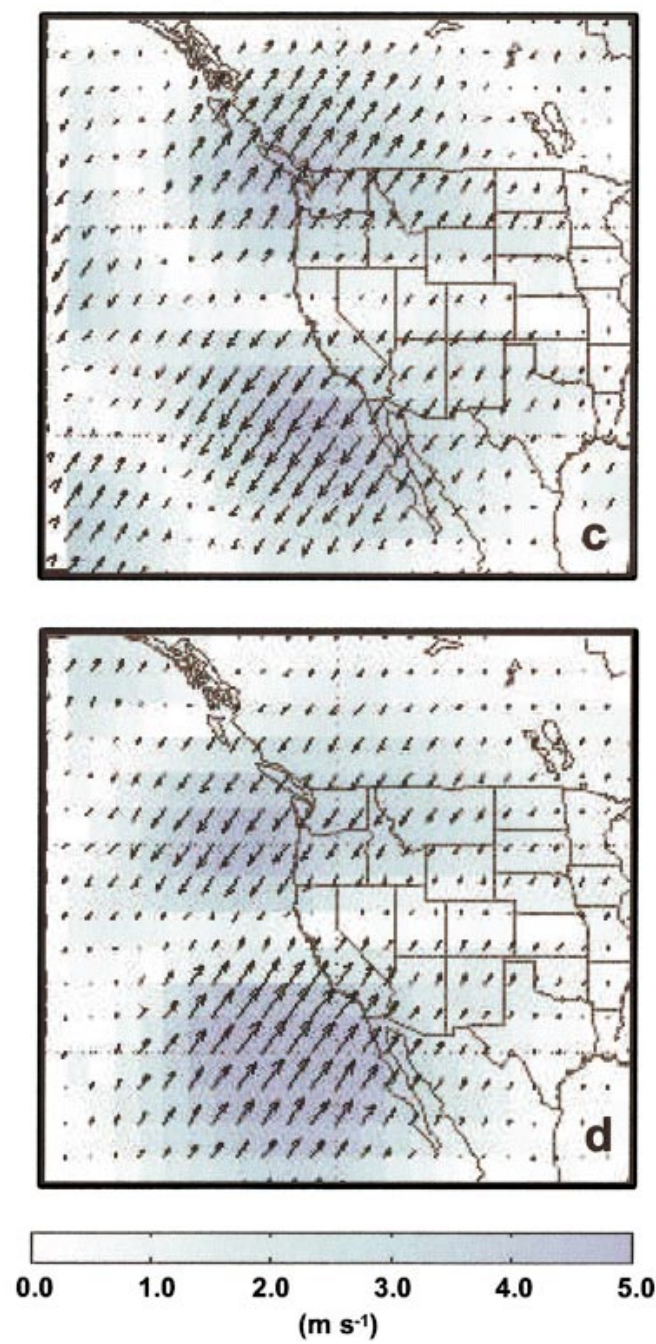

FIG. 9. (left) Average composites of daily springtime anomalies of $Z_{700}$ (contours) and total sky cover (color shading) during high and low ETo days minus the average conditions during normal ETo days and (right) average wind speed (shading) and direction (arrows) according to each ETo condition. The ETo days were classified as terciles of the mean standardized ETo anomalies for 29 CIMIS stations from 1990 to 2002. Contours are every 5 m. Negative contours are dashed.

$T_{\text {avg }}$ pattern than during spring. Of the CIMIS variables, $T_{\text {avg }}$ is the most strongly correlated with the circulation, especially during summer, but has less influence on ETo than $R_{n}$ and $\mathrm{RH}$. Very similar correlation patterns are obtained at all time scales and at several pressure levels (not shown). In general, the center of the correlation patterns tilt southward with height in the atmosphere.

The correlation pattern shown in Fig. 8 suggests that ETo (and the other variables) are strongly influenced by interplays between coastal-marine and continental air masses. During the spring, days with low pressures $\left(Z_{700}\right)$ offshore are associated with anomalously southwesterly winds and more than normal cloud cover in most of California (Fig. 9) and, as a consequence, lower than normal ETo. Spring days with high pressures off- shore experience a blocking of westerly flows into the state with less cloudiness and are characterized by high ETo rates (Fig. 9). A similar configuration of pressures operates in the summer, although the correlations are significantly lower, and the center of the ETo circulation pattern is displaced slightly inland, yielding broad atmospheric subsidence, drying and warming of the air over the state, and resembling more the $T_{\text {avg }}$ correlation pattern (Fig. 8).

The relation of these circulation patterns to the potential for evapotranspiration can be verified, in part, by considering the longer $E_{\text {pan }}$ records (1965-2001) from a few locations in California. Correlations between $E_{\text {pan }}$ and $Z_{700}$ were shown to be very similar to the corresponding ETo pattern (Fig. 8a), regardless of time period 


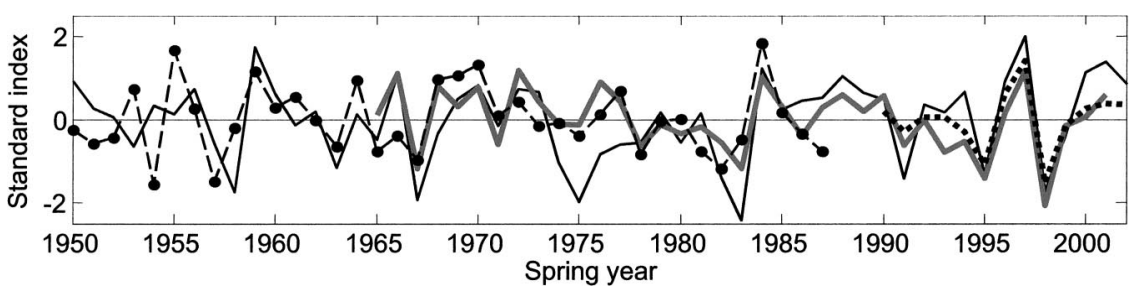

FIG. 10. Time series of spring seasonal-mean CPAI (thin line), standardized ETo (dotted line), cloud cover multiplied by -1 (circular markers), and $E_{\text {pan }}$ (thick gray line) data from California stations. The ETo values represent the mean of 29 stations, the $E_{\mathrm{pan}}$ values represent the mean of 7 stations, and the cloud cover is the mean of 5 stations.

considered (not shown). The pattern and magnitude of CIMIS $T_{\text {avg }}$ daily and monthly correlations with $Z_{700}$ (Fig. 8) were also verified using temperatures from 165 NCDC stations (not shown).

\section{b. Relations of regional atmospheric circulations with large-scale climate}

The springtime circulation pattern associated with ETo variations (Figs. 8 and 9) represents the long-term average connection between $Z_{700}$ and the CIMIS surface variables. The pattern is an average and thus would obscure some of the different circulation patterns that contribute to ETo variations, especially those which infrequently recur over the region.

The springtime pattern is similar to the correlation patterns between winter sea level pressure and December-August streamflow in the Sacramento River (Fig. 6 of Cayan and Peterson 1989). The streamflow-correlation pattern, called the California Pressure Anomaly (CPA; Cayan and Peterson 1989), has roughly the same areal extent but is centered $\left(40^{\circ} \mathrm{N}, 130^{\circ} \mathrm{W}\right)$ farther north than the patterns of Figs. 8 and 9. Low wintertime pressures in the CPA region are associated with large streamflows. Similar patterns were found by Mo (1999) and Mo and Higgins (1998) in several atmospheric circulation variables associated with California wintertime precipitation. Another possibility, given that our focus is on spring and summer, is that the patterns shown in Figs. 8 and 9 might actually be related to the position and influences of the North Pacific High (NPH) pattern (Hameed et al. 1995). The NPH is a synoptic feature characterized by a very persistent region of high pressure off the coast of North America. The spring pattern shown here, however, is not the NPH as such, as the NPH is not stationary in space and it is generally located farther offshore, although it sometimes could ridge over the Pacific Northwest (Navy 2004). During the wintertime the NPH presents lower intensity and displaces south (Dorman and Winant 1995; Navy 2004). The normal position of the NPH during the summer is north of Hawaii (around $30^{\circ} \mathrm{N}$ ), and during the winter it is between San Francisco and the north of Hawaii (around $40^{\circ} \mathrm{N}$; Dorman and Winant 1995; Navy 2004). The correlation (1950-95) of spring means of the CPA-like index (CPAI) and an index representing the intensity of the NPH (Shi 1999; Hameed et al. 1995) is +0.31 ( $p$ $\cong 0.05$ ). The correlation of the spring-mean CPAI and the latitude of the spring center of action of the NPH is $+0.36(p<0.05)$. Similar correlation for the longitude of the spring center of action of the NPH is +0.37 $(p<0.05)$.

On a seasonal basis, the CPAI developed here is strongly correlated with ETo, $E_{\mathrm{pan}}$, and cloud cover $\left[r_{\text {median }}=0.72(p<0.01), 0.61(p<0.01)\right.$, and $r=$ $0.40(p<0.05)$, respectively]. From 1950 to 2002, a weighted average of daily $Z_{700}$ values was calculated for points in Fig. 8 with correlations greater than or equal to 0.40 , weighted by those correlations. The springtime CPAI series, and standardized springtime means of ETo, $E_{\text {pan }}$, and cloud cover are compared in Fig. 10. The CPAI has a local influence on precipitation and a regional influence on temperature, as the CPAI pattern is significantly correlated with springtime temperature variations into Nevada and Arizona (Fig. 11). The CPAI influence on surface RH is also relatively localized to California (Fig. 11). It is interesting to note that the correlations of the CPAI with RH have opposite signs for the land and the sea, with steep gradients between, suggesting greater RH land-sea contrasts during extreme values of the CPAI (and thus also of ETo). Correlations of the CPAI with outgoing longwave radiation (a proxy for cloudiness) are consistent with the precipitation correlation pattern. The OLR interannual correlation pattern also is similar to the OLR-composite patterns found by Mo (1999; cf. Mo's Fig. 5) and Mo and Higgins (1998; cf. their Fig. 3a), which are thought to be related to intraseasonal precipitation oscillations (10-90-day period) in California during the winter. Correlations of the filtered (10-90 days) CPAI and OLR daily anomalies during the spring presented a characteristic three-cell pattern depicted in Mo and Higgins (1998; not shown). The three-cell pattern is also seen in the OLR and precipitation rate season-mean correlations with the CPAI (Fig. 11). Heavy wintertime precipitation in California (middle cell of the three-cell pattern) is associated with dry conditions over Washington, British Columbia, Canada, and the eastern Gulf of Alaska (northernmost cell of the pattern), and also with reduced precipitation over the subtropical eastern 

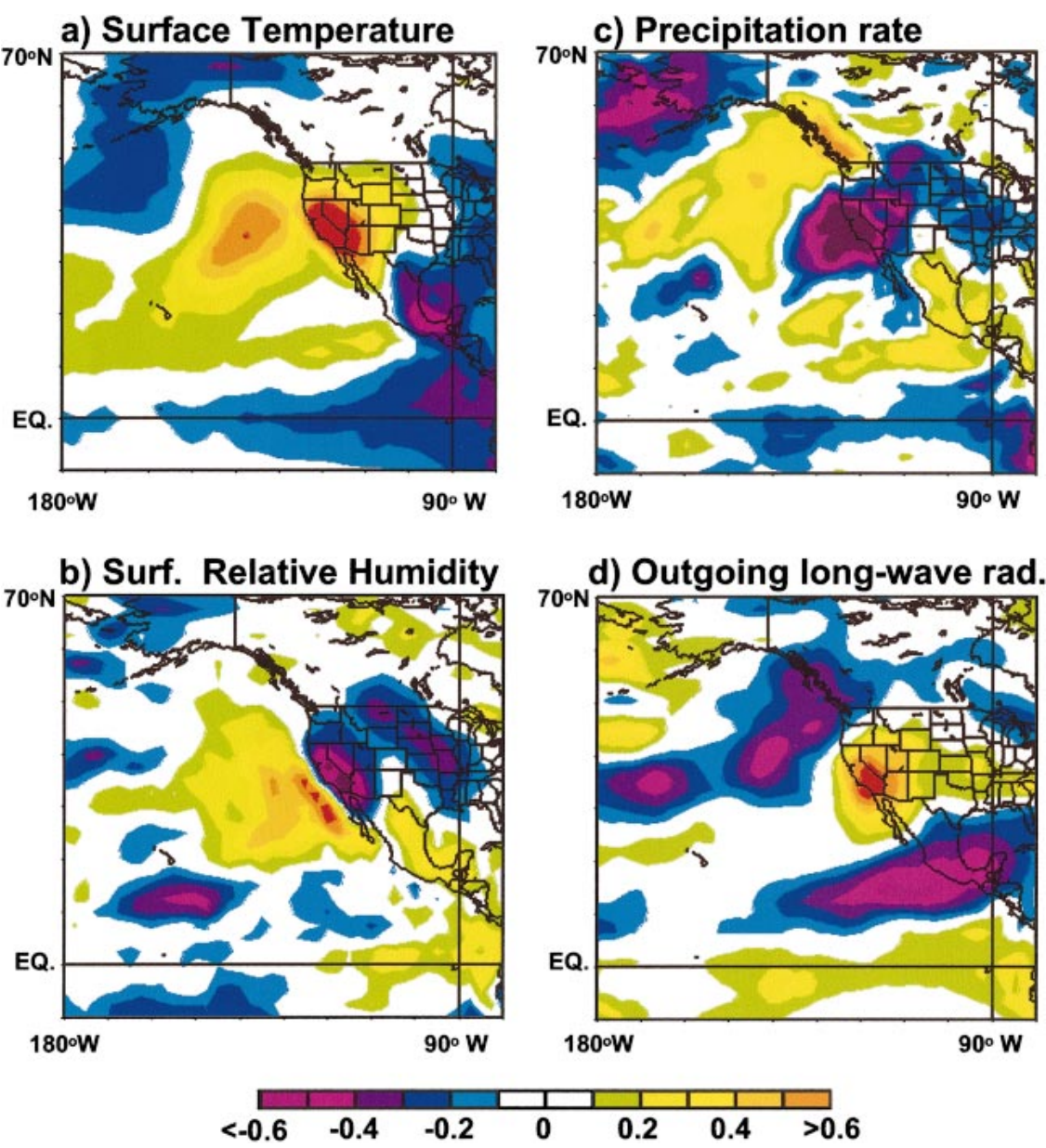

FIG. 11. Correlations between springtime seasonal-mean CPAI and data from the NCEPNCAR reanalysis.

Pacific and Mexico (southernmost cell; Mo and Higgins 1998). The seesaw between northern British Columbia and California is a more consistent pattern, which is related to moisture transport. The seesaw between California and the subtropics, although having a dynamical support, depends on the strength of the Hadley cell, which is a reflection of convection in the subtropics (Mo and Higgins 1998; K. C. Mo 2004, personal communication). In our analysis, the local (middle) pattern over California defined by the CPAI was correlated with the other poles of the three-cell pattern during the spring, at 10-90 days and at interannual time scales (using seasonal-mean correlations). However, the connections of California precipitation (or cloudiness) with the subtropics during the spring have to be verified with more research, as the Mo and Higgins (1998) study focused on winter processes and the Northern Hemisphere Hadley cell weakens progressively from winter to summer (Dima and Wallace 2003).

Although the very strong El Niño events of 1982/83 and 1997/98 yielded unusually low spring CPAI values, this tendency was not generally evident in other El Niño events during 1950-2002. This may reflect the tendency for large El Niño events to persist through boreal winter into the spring season. La Niña springs also are not consistently associated with high spring CPAI. Therefore, there is no strong ENSO signal in springtime CPAI or ETo. For example, the correlation between springtime Niño-3 SST anomalies and the CPAI is nonsignificant $[r=-0.22(p>0.05)]$. The same type of correlation for the winter is $-0.41(p<0.01)$, suggesting that during this season, the CPAI may be a feature related to the linear part of the extratropical response to ENSO.

\section{Historical trends and implications for climate change}

Declining $E_{\mathrm{pan}}$ rates have been reported in some regions of the United States and have been attributed to changes in radiation, sunlight reaching the surface, and cloudiness (Roderick and Farquhar 2002; Peterson et al. 1995; Lawrimore and Peterson 2000). In contrast, no significant springtime $E_{\mathrm{pan}}$ trends are present at five of seven California stations (Table 5). Even the signs of 
TABLE 5. Annual and springtime trends of (a) pan evaporation data and (b) cloud-cover data for California stations. Significant trends at the 0.05 level are italic.

\begin{tabular}{lcc}
\hline \hline (a) Pan evaporation trends (1965 $\begin{array}{c}\text { to 2001) } \\
\text { Annual trend } \\
\text { Name }\end{array}$ & $\begin{array}{c}\text { Spring trend } \\
\left(\mathrm{mm} \mathrm{yr}^{-1}\right)\end{array}$ \\
\hline Cachuma Dam & -1.5019 & +0.3136 \\
Davis & +3.8009 & +0.5820 \\
Death Valley & -33.6705 & -9.1789 \\
Friant Government Camp & -4.1267 & +1.1494 \\
San Luis Dam & -3.4687 & -0.5631 \\
Shasta Dam & +4.1212 & +0.4818 \\
Lodi & -5.6219 & -1.8858 \\
(b) Cloud-cover trends (1950 to & $1987)$ & \\
$\quad$ Annual trend & Spring trend \\
$\quad$ Name & $\left(\% \mathrm{yr}^{-1}\right)$ & $\left(\% \mathrm{yr}^{-1}\right)$ \\
\hline Eureka & -0.1097 & -0.1338 \\
Red Bluff & +0.1180 & +0.0240 \\
Fresno & +0.1917 & +0.0375 \\
Los Angeles & -0.0234 & -0.0891 \\
Sacramento & +0.0769 & -0.02173 \\
San Francisco & +0.0347 & +0.0176 \\
San Diego & +0.1758 & +0.08123 \\
\hline
\end{tabular}

$E_{\text {pan }}$ trends at stations relatively close to each other (e.g., Davis and Lodi) have differed (Table 5). Thus, there have been no strong or consistent overall springtime $E_{\mathrm{pan}}$ trend in California.

In California, radiation (and cloudiness) changes that may cause $E_{\mathrm{pan}}$ and ETo trends (in the future) are associated with springtime atmospheric circulations that can be indexed by the CPAI. However, historically, the springtime and annual CPAI show no significant trends from 1950 to 2002, and few of the cloud-cover stations reported significant trends (Tables 5 and 6). Over the same period, however, there have been significant trends toward more springtime precipitation at many NCDC sites. This precipitation trend is not particularly consistent with the lack of trends in cloud cover, but inspection of the precipitation time series reveals that many of the precipitation trends reflect a step change toward wetter conditions in 1976/77. This climatic shift is part of a seemingly natural, large-scale circulation change that affected many environmental and physical variables in North America (Ebbesmeyer et al. 1991; Mantua et al. 1997). Overall, it appears that the lack of historical springtime $E_{\text {pan }}$ and ETo trends reflects a weakness or lack of trends in their primary radiative forcings.

Temperature trends may also affect ETo in California (eventually). In California, ETo's temperature dependence is largely limited to daytime temperatures, which can be indexed by daily maximum temperatures $\left(T_{\max }\right)$. Springtime and annual $T_{\max }$ series in California have small (usually nonsignificant) and less consistent positive trends than have minimum temperatures $\left(T_{\min }\right)$. At nonurban stations (those where population density $<$ 120 habitants $\mathrm{km}^{-2}$ ), the $T_{\max }$ trends are even smaller and less significant (Table 5; Goodridge 1992).

Although historical springtime evaporation demands in California have not trended significantly, future climate changes may affect them. Current climate models project twenty-first century warmings of between about $3^{\circ}$ and $6^{\circ} \mathrm{C}$ over California in response to "business-asusual" greenhouse-gas emission scenarios (e.g., Dettinger 2004). In response to $\mathrm{a}+3^{\circ} \mathrm{C}$ uniform warming of $\mathrm{T}_{\text {avg }}$, Eq. (1) (with unchanged 1990-2002 CIMIS meteorological data applied otherwise) indicates that annual ETo totals could increase by $6 \%$ (Fig. 12). Note that although temperatures play only a secondary role in determining California ETo variability, $T_{\text {avg }}$ trends could still be reflected as ETo trends, as the lack of strong intercorrelation between $T_{\text {avg }}$ and ETo anomalies (presented in section 3b) does not preclude this effect according to Eq. (1). That is, ETo's driving meteorological inputs $\left(R_{n}, T_{\text {avg }}, \mathrm{RH}\right.$, and $\left.U\right)$ used in Eq. (1) include trends and seasonal cycles of the variables, while the correlations between these inputs and ETo

TABLE 6. Annual and spring-mean trends in 1) precipitation and air temperature for two sets of NCDC California stations and 2) the spring CPAI. Trends significant at the 0.05 level are italic. Low population density stations are those located in areas where population density is less than 120 habitants $\mathrm{km}^{-2}$. Data are from 1950 to 2000.

\begin{tabular}{|c|c|c|c|c|}
\hline \multirow[b]{2}{*}{ Variable } & \multicolumn{2}{|c|}{ Annual } & \multicolumn{2}{|c|}{ Spring } \\
\hline & Median trend & $\begin{array}{l}\text { Percentage of } \\
\text { stations reporting } \\
\text { positive trends }\end{array}$ & Median trend & $\begin{array}{l}\text { Percentage of } \\
\text { stations reporting } \\
\text { positive trends }\end{array}$ \\
\hline \multicolumn{5}{|l|}{$\begin{array}{l}\text { Surface variables: } \\
\text { All stations (165 stations): }\end{array}$} \\
\hline $\begin{array}{l}\text { Precipitation } \\
\text { Maximum temperature } \\
\text { Minimum temperature }\end{array}$ & $\begin{array}{l}+1.0644 \mathrm{~mm} \mathrm{yr}^{-1} \\
+0.0071^{\circ} \mathrm{C} \mathrm{yr}^{-1} \\
+0.0241^{\circ} \mathrm{C} \mathrm{yr^{-1 }}\end{array}$ & $\begin{array}{l}88 \% \\
65 \% \\
84 \%\end{array}$ & $\begin{array}{l}+3.2804 \mathrm{~mm} \mathrm{yr}^{-1} \\
+0.0169^{\circ} \mathrm{C} \mathrm{yr}^{-1} \\
+0.0325^{\circ} \mathrm{C} y r^{-1}\end{array}$ & $\begin{array}{l}89 \% \\
77 \% \\
94 \%\end{array}$ \\
\hline \multicolumn{5}{|c|}{ Low population density stations (116 stations): } \\
\hline $\begin{array}{l}\text { Precipitation } \\
\text { Maximum temperature } \\
\text { Minimum temperature }\end{array}$ & $\begin{array}{l}+0.9617 \mathrm{~mm} \mathrm{yr}^{-1} \\
+0.0042^{\circ} \mathrm{C} \mathrm{yr}^{-1} \\
+0.0221^{\circ} \mathrm{C} \mathrm{yr}^{-1}\end{array}$ & $\begin{array}{l}86 \% \\
60 \% \\
81 \%\end{array}$ & $\begin{array}{l}+2.8688 \mathrm{~mm} \mathrm{yr}^{-1} \\
+0.0131^{\circ} \mathrm{C} \mathrm{yr}^{-1} \\
+0.9708^{\circ} \mathrm{C} y r^{-1}\end{array}$ & $\begin{array}{l}88 \% \\
70 \% \\
92 \%\end{array}$ \\
\hline \multicolumn{3}{|l|}{ Atmospheric variables: } & $-0.0242 \mathrm{yr}^{-1}$ & \\
\hline
\end{tabular}




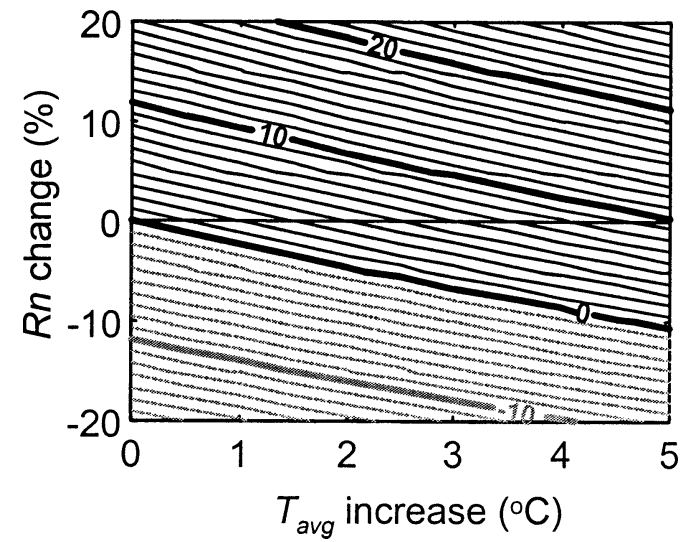

FIG. 12. Median percentage change in total annual ETo(\%) due to prescribed uniform increases in $T$ and percentage changes of $R_{n}$ considering no change in $\mathrm{RH}$ and $U_{\text {avg }}$. The contours were plotted using the median values of meteorological inputs from 29 California stations during 1990-2002. Positive (negative) contours solid (dashed) black (gray) curves.

(section 3b) were computed from the anomalies of the variables (seasonal cycles and trends removed). Projections of $R_{n}$ trends are generally not available and have not been studied. Projections of twenty-first century precipitation might provide some hints about the future of $R_{n}$ but are notably less unanimous than the temperature projections, with even the signs of projected precipitation changes differing from projection to projection (Dettinger 2004). However, to put the role of future $R_{n}$ changes into perspective, we note that a reduction of $R_{n}$ by about $6 \%$ would be required to mitigate the projected $3^{\circ} \mathrm{C}$ warming influence on ETo (Fig. 12); any increases in $R_{n}$ would rapidly aggravate the warming-induced ETo trends. For reference, the standard deviation of annual ETo is typically around 5\% (Table 2), so that ETo responses of these magnitudes would be large and observable in CIMIS data.

\section{Concluding discussion}

The annual demand of water is greater than the supply of accumulated precipitation for all of the relatively low elevation stations for which we can estimate ETo. However, precipitation in California arrives in sporadic storms, with many dry days in between, while ETo is much more smoothly distributed throughout the seasons. Although the variability of annual precipitation totals is also much larger than those of ETo totals, ETo variability is important because of its impacts upon water resources and agricultural management. The ETo variations are largest in spring when precipitation variability is muted and thus have significant influences upon the overall hydrologic cycle in California.

Daily ETo anomalies in California are most variable during spring. This large variability is associated with the generally large ETo values, due to the season's high surface irradiance (compared to winter and autumn), which is interrupted by occasional ETo reductions associated with cloudy days. This combination of high seasonal values with strong cloud interference is not common to the other seasons. Daily ETo anomalies are most strongly correlated with $R_{n}$ and $\mathrm{RH}$, and less so with $T_{\text {avg }}$ (especially during spring). The strong relation between ETo and $R_{n}$ compared to $T_{\text {avg }}$ is also evidenced by the shorter decorrelation times shared by ETo and $R_{n}$, suggesting faster and more local controls on ETo and $R_{n}$ (i.e., cloudiness) than on $T_{\text {avg }}$.

ETo and associated meteorological variations are driven by the regional atmospheric circulation. A characteristic circulation pattern influences daily, monthly, and seasonal variations of ETo, $R_{n}, T_{\text {avg }}, \mathrm{RH}$, and $U_{\text {avg }}$ anomalies. High cloudiness and lower than normal ETo values are associated with low-height (pressure) anomalies centered immediately offshore from central California, in a CPA-like circulation pattern (Cayan and Peterson 1989). Conversely, higher than normal ETo anomalies are associated with clear skies maintained by a high pressure center off the central California coast.

Statewide springtime cloudiness and $E_{\mathrm{pan}}$ and ETo conditions in California did not trend appreciably during the last part of the twentieth century. Average $T_{\min }$ temperatures for 165 California stations showed significant increasing trends from 1950 to 2001, but $T_{\max }$ - which is more directly associated with ETo variability-did not generally trend significantly during the twentieth century. However, significant temperature increases in the twenty-first century under the influences of increasing greenhouse gases are suggested by the climate projections from general circulation models (GCMs). The typical range of temperature increase projected by the GCMs would increase ETo significantly, unless mitigated by changes in $R_{n}$. The future of $R_{n}$ remains uncertain, in large part because the disposition of cloud cover under climate change is not known. Moderate (one standard deviation) changes in annual ETo would be projected from the Penman equation [(1)] in response to realistic future changes in temperature and radiation. However, more subtle changes should also be investigated; for example, those related to the changes in the hourly distributions of cloud cover, changes related to nonuniform increases in temperature and radiation, and to ETo's differing sensitivities to $T_{\max }$ and $T_{\min }$.

This paper was focused on the variability of ETo because of its importance for quantifying water demand and its widespread use for scheduling irrigation. In other applications, such as for closing water balances, climate change studies, and hydrological models, it may be necessary to analyze ETa estimates. Although approximate methods are available for the estimation of ETa from ETo and $R_{n}$ (Bouchet 1963) and from hydrologic models (Knowles 2002; Knowles and Cayan 2002), more lysimeter measurements are needed in order to improve ETa estimates. High-resolution $(<1 \mathrm{~km})$ land-cover data would also improve our estimates of hydrological and evapotranspiration conditions, while more high-eleva- 
tion meteorological stations are needed to provide a better understanding of forest evapotranspiration processes. Additional CIMIS-like stations in northernmost California and in the southern deserts are needed to complement the information provided by the CIMIS system.

Acknowledgments. This work was funded by grants from the California Department of Water Resources (Contract 4600002292), the California Energy Commission through the California Climate Change Center at SIO, and the U.S. Department of Energy. Figure 11 was created using the tools provided by NOAA's Climate Prediction Center with the help of Cathy Smith. We thank Bekele Temesgen from CIMIS who provided useful information about the dataset and Kingtse Mo for her helpful comments. We thank the three anonymous reviewers and the chief editor of the Journal of Hydrometeorology, Dennis Lettenmaier, for their constructive comments, which enhanced the overall impact of this paper.

\section{REFERENCES}

Alexandris, S., and P. Kerkides, 2003: New empirical formula for hourly estimations of reference evapotranspiration. Agric. Water Manage., 60, 157-180.

Bouchet, R. J., 1963: Evapotranspiration réelle evapotranspiration potentielle, signification climatique. Int. Assoc. Sci. Hydrol., 62, 134-142.

Cayan, D. R., and D. H. Peterson, 1989: The influence of North Pacific circulation on streamflow in the west. Aspects of Climate Variability in the Pacific and Western America, Geophys. Monogr., No. 55, Amer. Geophys. Union, 375-398.

Chiew, F. H. S., and T. A. McMahon, 1992: An Australian comparison of Penman potential evapotranspiration estimates and class-A evaporation pan data. Aus. J. Soil Res., 30, 101-112.

Dettinger, M. D., 2004: From climate-change spaghetti to climatechange distributions for 21 st century California. San Francisco Estuary Watershed Sci., in press.

Dima, I. M., and J. M. Wallace, 2003: On the seasonality of the Hadley cell. J. Atmos. Sci., 60, 1522-1527.

Dong, A., S. R. Grattan, J. J. Carroll, and C. R. K. Prashar, 1992: Estimation of daytime net radiation over well-watered grass. $J$. Irrig. Drain. Eng., 118, 466-479.

Dorman, C. E., and C. D. Winant, 1995: Buoy observations of the atmosphere along the west coast of the United States. J. Geophys. Res., 100, $16029-16044$.

Ebbesmeyer, C. C., D. R. Cayan, D. R. McClain, F. H. Nichols, D. H. Peterson, and K. T. Redmond, 1991: 1976 step in Pacific climate: Forty environmental changes between 1968-1975 and 1977-1984. California Department of Water Resources, Interagency Ecological Study Program Tech. Rep. 26, 235 pp.

Goodridge, J. D., 1992: Urban bias influences on long-term California air temperature trends. Atmos. Environ., 26B, 1-7.

Grismer, M. E., M. Orang, R. Snyder, and R. Matyac, 2002: Pan evaporation to reference evapotranspiration conversion methods. J. Irrig. Drain. Eng., 128, 180-184.

Hameed, S., W. Shi, J. Boyle, and B. Santer, 1995: Investigation of the centers of action in the northern Atlantic and North Pacific in the ECHAM AMIP simulation. Proc. First Int. AMIP Scientific Conf., Monterey, CA, WCRP-92, WMO Tech. Doc. 732, 221226.

Hargreaves G. H., and R. G. Allen, 2003: History and evaluation of Hargreaves evapotranspiration equation. J. Irrig. Drain. Eng., 129, 53-63.
Hargreaves, G. L., G. H., Hargreaves, and J. P. Riley, 1985: Irrigation water requirements for Senegal River basin. J. Irrig. Drain. Eng., 111, 265-275.

Hope, A. S., and S. M. Evans, 1992: Estimating reference evaporation in the Central Valley of California using the Linacre model. Water Resour. Bull., 28, 695-702.

ITRC, 2003: California crop and soil evapotranspiration for water balances and irrigation scheduling/design. Irrigation Training and Research Center Rep. ITRC 03-001, California Polytechnic State University, San Luis Obispo, CA, 57 pp.

Kalnay, E., and Coauthors, 1996: The NCEP/NCAR 40-Year Reanalysis Project. Bull. Amer. Meteor. Soc., 77, 437-471.

Karl, T. R., and P. M. Steurer, 1990: Increased cloudiness in the United States during the first half of the twentieth century: Fact or fiction? Geophys. Res. Lett., 17, 1925-1928.

Kistler, R., and Coauthors, 2001: The NCEP-NCAR 50-year reanalysis: Monthly means CD-ROM and documentation. Bull. Amer. Meteor. Soc., 82, 247-268.

Knowles, N., 2002: Natural and management influences on freshwater inflows and salinity in the San Francisco Estuary at monthly to interannual scales. Water Resour. Res., 38, 1289, doi:10.1029/ 2001WR000360.

— , and D. R. Cayan, 2002: Potential effects of global warming on the Sacramento/San Joaquin watershed and the San Francisco Estuary. Geophys. Res. Lett., 29, 1891, doi:10.1029/ 2001GL014339.

Koppen, W., 1936: Das geographische System der Klimate. Handbuch der Klimatologie, W. Koppen and R. Geiger, Eds., Borntraeger, $46 \mathrm{pp}$.

Lawrimore, J. H., and T. C. Peterson, 2000: Pan evaporation trends in dry and humid regions of the United States. J. Hydrometeor., 1, 543-546.

Lee, R., 1980: Forest Hydrology. Columbia University Press, 349 pp.

Lile, D. F., and M. R. George, 1993: Prediction of pasture growth rates from climatic variables. J. Prod. Agric., 6, 86-90.

Manabe, S., R. T. Wetherald, P. C. D. Milly, T. L. Delworth, and R. J. Stouffer, 2004: Century-scale change in water availability$\mathrm{CO}_{2}$-quadrupling experiment. Climatic Change, 62, 5147014, doi:10.1023/B:CLIM.0000024674.37725ca.

Mantua, N. J., S. R. Hare, Y. Zhang, J. M. Wallace, and R. C. Francis, 1997: A Pacific interdecadal climate oscillation with impacts on salmon production. Bull. Amer. Meteor. Soc., 78, 1069-1079.

Mo, K. C., 1999: Alternating wet and dry episodes over California and intraseasonal oscillations. Mon. Wea. Rev., 127, 2759-2776.

- and R. W. Higgins, 1998: Tropical influences on California precipitation. J. Climate, 11, 412-430.

Monteith, J. L., 1965: Evaporation and the environment. Symp. Soc. Expl. Biol., 19, 205-234.

- 1973: Principles of Environmental Physics. Edward Arnold, $242 \mathrm{pp}$.

Navy, cited 2004: Forecaster's handbook. Geophysics Branch, Naval Air Warfare Center, China Lake, CA. [Available online at http://www. nawcwpns.navy.mil/ weather/chinalake/fcstrhndbk/TOC.htm.]

Nogues-Paegle, J., and K. Mo, 1987: Spring-to-summer transitions of global circulations during May-July 1979. Mon. Wea. Rev., 115, 2088-2102.

Penman, H. L., 1948: Natural evaporation from open water, bare soil and grass. Proc. Roy. Soc. London, A193, 129-145.

Peterson, T. C., V. S. Golubev, and P. Y. Groisman, 1995: Evaporation losing its strength. Nature, 377, 687-688.

Prentice, K. C., 1990: Bioclimatic distribution of vegetation for general circulation model studies. J. Geophys. Res., 95D, 11 81111830 .

Pruitt, W. O., and J. Doorenbos, 1977: Empirical calibration, a requisite for evapotranspiration formulae based on daily or longer mean climatic data? Proc. Int. Round Table Conf. on Evapotranspiration, Budapest, Hungary, International Commission on Irrigation and Drainage, $20 \mathrm{pp}$

Rind, D., R. Goldberg, J. Hansen, C. Rozenzweig, and P. Ruedy, 
1990: Potential evapotranspiration and the likelihood of future drought. J. Geophys. Res., 95, 9983-10 004.

Roderick, M. L., and G. D. Farquhar, 2002: The cause of decreased pan evaporation over the past 50 years. Science, 298, 14101411 .

Satterlund, D. R., 1979: An improved equation for estimating longwave radiation from the atmosphere. Water Resour. Res., 15, 1649-1650.

Shi, W., 1999: On the relationship between the interannual variability of the Northern Hemispheric subtropical high and the east-west divergent circulation during summer. Ph.D. thesis, State University of New York at Stony Brook.

Shuttleworth, W. J., 1993: Evaporation. Handbook of Hydrology, D. R. Maidement, Ed., McGraw-Hill, 4.1-4.53
Steurer, P. M., and T. R. Karl, cited 2004: Historical sunshine and cloud data in the United States. Carbon Dioxide Information Analysis Center, U.S. Department of Energy. [Available online at http://cdiac.ornl.gov/home.html.]

Thornthwaite, C. W., 1948: An approach toward a rational classification of climate. Geogr. Rev., 38, 55-89.

van Wijk, W. R., and D. A. de Vries, 1963: Periodic temperature variations in homogeneous soil. Physics of the Plant Environment, W. R. van Wijk, Ed., North-Holland, 102-143.

$\mathrm{Xu}, \mathrm{C}$. Y., and V. P. Singh, 1998: Dependence of evaporation on meteorological variables at different time-scales and intercomparison of estimation methods. Hydrol. Processes, 12, $429-442$. 